\title{
The Behavior of Gangue During the Flotation of a Sulfidic PGM-Bearing Ore in Response to Various Monovalent and Divalent lons in Process Water
}

\author{
Malibongwe Shadrach Manono ${ }^{*}$, Kirsten Claire Corin and Jennifer Gael Wiese \\ Centre for Minerals Research, Department of Chemical Engineering, University of Cape Town, Cape Town, South Africa
}

\section{OPEN ACCESS}

Edited by:

Zhiyong Gao,

Central South University, China

Reviewed by:

Thuat Thanh Trinh,

Norwegian University of Science and

Technology, Norway

Sugata Chowdhury,

National Institute of Standards and

Technology (NIST), United States

*Correspondence: Malibongwe Shadrach Manono malibongwe.manono@uct.ac.za

Specialty section:

This article was submitted to

Physical Chemistry and Chemical

Physics,

a section of the journal

Frontiers in Chemistry

Received: 29 October 2019 Accepted: 23 January 2020 Published: 18 March 2020

Citation:

Manono MS, Corin KC and Wiese JG (2020) The Behavior of Gangue During the Flotation of a Sulfidic

PGM-Bearing Ore in Response to Various Monovalent and Divalent lons in Process Water. Front. Chem. 8:79.

doi: 10.3389/fchem.2020.00079
Mineral concentrators are becoming increasingly aware of the importance of the quality of the water that they feed into their milling and flotation circuits. It is speculated that different inorganic constituents of process water may yield different flotation results owing to the electrolyte-reagent-mineral interactions occurring in the pulp phase. These interactions are said to be specific to ion type, reagent type, and mineral or ore type. It therefore stands to reason that there is a need to develop an understanding of the specific ion effects on both the pulp phase and the froth phase phenomena, such that the chemistry and the quality of process water can be monitored and controlled in a manner that does not negatively affect the flotation performance. Previous research has shown that inorganic electrolytes may impact the hydrophobicity and the floatability of mineral particles and could in turn affect froth stability, entrainment, and thus mineral grades and recoveries. In this study, the floatability of a Cu-Ni-PGM-bearing Merensky ore is tested on a bench-scale flotation system in various single salt solutions, viz., $\mathrm{CaCl}_{2}$, $\mathrm{CaSO}_{4}, \mathrm{Ca}\left(\mathrm{NO}_{3}\right)_{2}, \mathrm{MgCl}_{2}, \mathrm{Mg}\left(\mathrm{NO}_{3}\right)_{2}, \mathrm{MgSO}_{4}, \mathrm{NaCl}, \mathrm{NaNO}_{3}$, and $\mathrm{Na}_{2} \mathrm{SO}_{4}$, in order to examine specific ion effects on gangue recovery. Coagulation and zeta potential tests are conducted in order to establish the nature of the impact that specific ions have on the behavior of gangue in flotation. The findings of this work have shown that single salt solutions containing $\mathrm{NO}_{3}^{-}$ions resulted in a strong depression of gangue compared to those solutions containing $\mathrm{Cl}^{-}$and $\mathrm{SO}_{4}{ }^{2-}$ ions. It was also shown that the divalent $\mathrm{Ca}^{2+}$ and $\mathrm{Mg}^{2+}$ showed a stronger depression of gangue compared to the monovalent $\mathrm{Na}^{+}$. $\mathrm{Ca}^{2+}$, in comparison to $\mathrm{Na}^{+}$, resulted in an increase in the coagulation of the ore as well as an increase in the zeta potential of talc. Overall, the findings of this paper suggest that the presence of $\mathrm{Ca}^{2+}$ and $\mathrm{Mg}^{2+}$ in process water would most likely create conditions that promote gangue depression.

Keywords: flotation, gangue, inorganic electrolytes, ions, sulfides, talc, water 


\section{RESEARCH KEY HIGHLIGHTS}

- Solutions containing $\mathrm{NO}_{3}^{-}$and $\mathrm{Ca}^{2+}$ increased the depression of gangue as shown by lower gangue recoveries.

- The concentrate grades were higher in solutions containing $\mathrm{Ca}^{2+}$ and $\mathrm{NO}_{3}^{-}$compared to those which contained $\mathrm{Na}^{+}, \mathrm{Cl}^{-}$, and $\mathrm{SO}_{4}{ }^{2-}$.

- $\mathrm{Ca}^{2+}$ and $\mathrm{NO}_{3}^{-}$resulted in a less negative zeta potential compared to $\mathrm{Na}^{+}$and $\mathrm{SO}_{4}{ }^{2-}$.

- Coagulation was enhanced in $\mathrm{Ca}^{2+}$ - and $\mathrm{NO}_{3}^{-}$containing solutions.

- $\mathrm{Ca}^{2+}$-containing process waters could be beneficial for floatable gangue depression.

\section{INTRODUCTION}

It is acknowledged that water should be considered as a reagent in flotation and, as such, the quality of process water becomes an important factor to consider as it may alter the pulp chemistry and thereby affect the flotation (Corin et al., 2011; Corin and Wiese, 2014). Previous work considered specific ions present in process water and their effects on the flotation of a Cu-Ni-PGM ore (Manono et al., 2016). Much of the conclusions made from Manono et al. (2016) gave rise to speculations of ions, being there in process water, which promoted gangue depression better than others. However, there was no fundamental evidence to support the speculation of an enhancement of gangue depression. Thus, the purpose of this study is to ascertain whether there are specific ion effects on gangue depression. As the separation of value-bearing minerals from the non-value-bearing gangue minerals is the core and fundamental purpose of flotation, the depression of gangue as a critical aspect of flotation is important to consider. Rao and Finch (1989) demonstrated that recycled water may negatively affect mineral recoveries and grades owing to an accumulation of inorganic and organic substances which alter the pulp chemistry and thereby affect the flotation. A study conducted by Muzenda (2010) showed that recycled process water containing $\mathrm{Cu}^{2+}, \mathrm{Pb}^{2+}$, and $\mathrm{Fe}^{2+}$ had adverse effects on the flotation of a PGM ore from the UG2 reef of the Bushveld Igneous Complex of South Africa in that there occurred an inadvertent activation of non-sulfide gangue which decreased the concentrate grades. This could be explained by a more recent study by Liu et al. (2014) which suggested that some electrolytes in process water could inhibit the adsorption of xanthates on sulfide minerals due to competition for adsorption onto the mineral surface. Also, Castro et al. (2013) showed that the flotation of molybdenite in the presence of $\mathrm{Mg}^{2+}$ ions resulted in molybdenite depression due to the presence of magnesium hydroxyl complexes and colloidal magnesium hydroxide coatings on molybdenite particles, rendering them hydrophilic. Laskowski et al. (2007) also showed that the presence of high $\mathrm{Ca}^{2+}$ concentration in process water improved the adsorption of CMC onto talc through an acid-base interaction and thus promoted the depression of talc. Biçak et al. (2012) concluded that dissolved metal ions and sulfide ions mainly in the form of $\mathrm{SO}_{4}{ }^{2-}$ and $\mathrm{S}_{2} \mathrm{O}_{3}{ }^{2-}$ alter the surface chemistry of minerals in the pulp phase. Ikumapayi et al. (2012) also showed that galena was

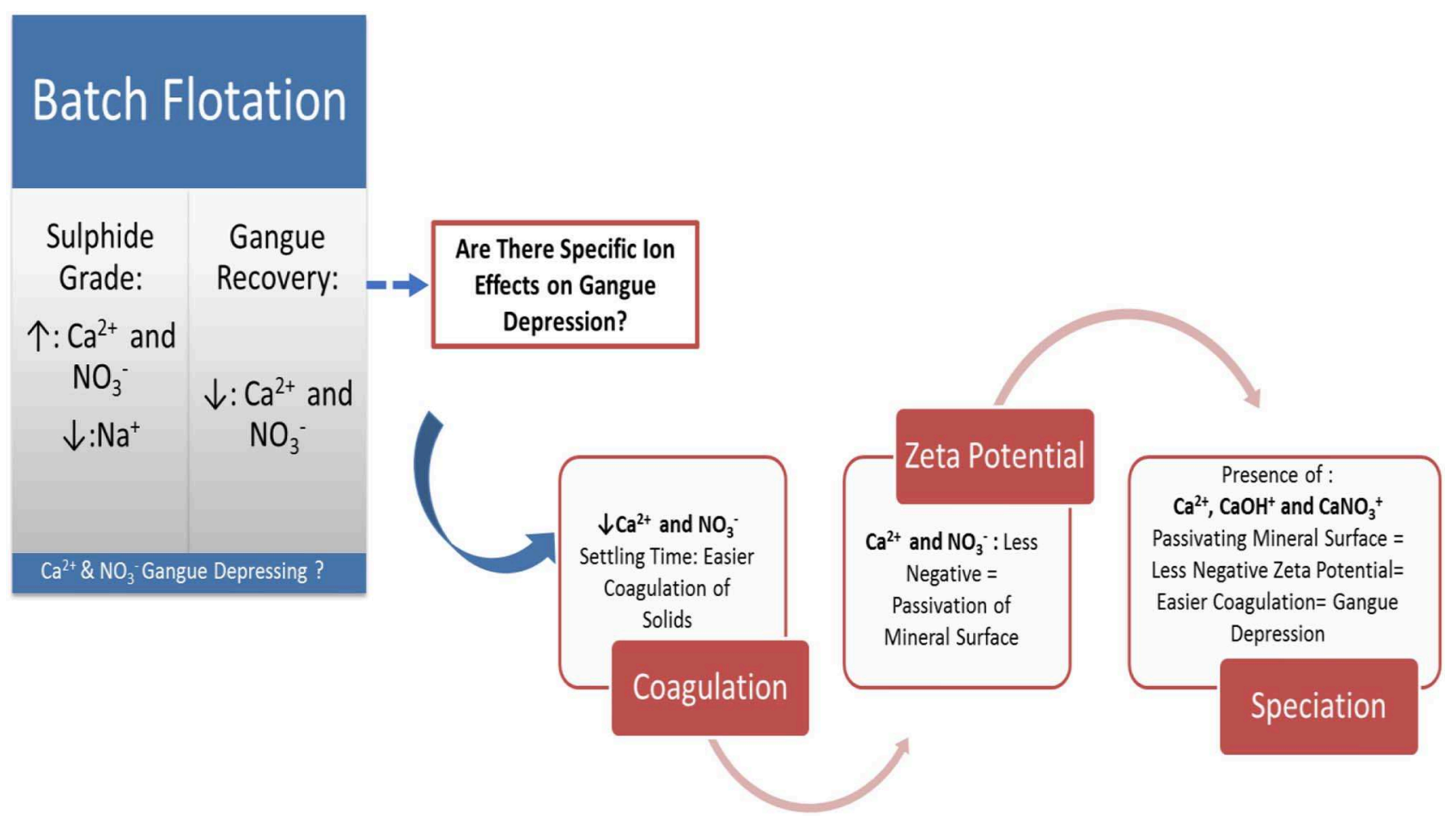

GRAPHICAL ABSTRACT | A schematic summary of the research findings presented in this paper. 
TABLE 1 | Chemical compositions of synthetic plant water and the various single salt solutions tested in this study.

\begin{tabular}{|c|c|c|c|c|c|c|c|c|c|}
\hline $\begin{array}{l}\text { Water } \\
\text { type }\end{array}$ & $\begin{array}{c}\mathrm{Ca}^{2+} \\
(\mathrm{mg} / \mathrm{l})\end{array}$ & $\begin{array}{l}\mathrm{Mg}^{2+} \\
(\mathrm{mg} / \mathrm{l})\end{array}$ & $\begin{array}{c}\mathrm{Na}^{+} \\
(\mathrm{mg} / \mathrm{l})\end{array}$ & $\begin{array}{c}\mathrm{Cl}^{-} \\
(\mathrm{mg} / \mathrm{l})\end{array}$ & $\begin{array}{l}\mathrm{SO}_{4}{ }^{2-} \\
(\mathrm{mg} / \mathrm{l})\end{array}$ & $\begin{array}{l}\mathrm{NO}_{3}^{-} \\
(\mathrm{mg} / \mathrm{l})\end{array}$ & $\begin{array}{l}\mathrm{CO}_{3}{ }^{2-} \\
(\mathrm{mg} / \mathrm{l})\end{array}$ & $\begin{array}{l}\text { Total dissolved solids } \\
\text { (mg/l) }\end{array}$ & $\begin{array}{c}\text { lonic strength } \\
{[\mathrm{M}]}\end{array}$ \\
\hline 1SPW & 80 & 70 & 153 & 287 & 240 & 176 & 17 & 1,023 & 0.0213 \\
\hline $\mathrm{NaCl}$ & - & - & 490 & 755 & - & - & - & 1,245 & 0.0213 \\
\hline $\mathrm{Na}_{2} \mathrm{SO}_{4}$ & - & - & 326 & - & 682 & - & - & 1,009 & 0.0213 \\
\hline $\mathrm{NaNO}_{3}$ & - & - & 490 & - & - & 1,321 & - & 1,810 & 0.0213 \\
\hline $\mathrm{CaCl}_{2}$ & 285 & - & - & 503 & - & - & - & 788 & 0.0213 \\
\hline $\mathrm{CaSO}_{4}$ & 213 & - & - & - & 512 & - & - & 725 & 0.0213 \\
\hline $\mathrm{Ca}\left(\mathrm{NO}_{3}\right)_{2}$ & 285 & - & - & - & - & 880 & - & 1,165 & 0.0213 \\
\hline $\mathrm{MgCl}_{2}$ & - & 173 & - & 503 & - & - & - & 676 & 0.0213 \\
\hline $\mathrm{MgSO}_{4}$ & - & 129 & - & - & 512 & - & - & 641 & 0.0213 \\
\hline $\mathrm{Mg}\left(\mathrm{NO}_{3}\right)_{2}$ & - & 173 & & - & - & 880 & - & 1,053 & 0.0213 \\
\hline
\end{tabular}

more passivated in $\mathrm{Ca}^{2+}$ and $\mathrm{SO}_{4}{ }^{2-}$ and, as a result, mineral recoveries were reduced. Shackleton et al. (2012) investigated the water quality effects on moncheite-pyroxene and pentlanditepyroxene composites and proposed that ions found in process waters passivated the mineral surfaces and inhibited the collector adsorption, thereby reducing the floatability of moncheite, pentlandite, and pyroxene. Their findings also suggested that the specific ions in the process water played a far more significant role compared to the overall ionic strength of the process water. This therefore forms the basis of the work carried out in the study presented in this paper. It is evident, from the literature presented, that fundamental, robust, and more comprehensive studies on the effects of specific inorganic electrolytes on the floatability of sulfidic PGM ores are needed. Knowledge of the influence of each specific process water constituent on flotation is vital as it would potentially have both technical and financial benefits in that costs could be saved on wastewater treatment if research proves that some flotation circuits could still perform at their best in recycled process water containing constituents such as inorganic electrolytes which would have been removed due to limited knowledge of their specific impact on flotation performance. Such in-depth research knowledge is crucial in the development and implementation of closed water circuits in mineral concentrators. It is anticipated that understanding the impact of different process water constituents, leading to a successful implementation of closed water circuits, will contribute toward the sustainability of mineral concentrators as a result of minimal or zero process water discharge to the environment, minimal make-up water requirement, a reduction in process water treatment before reuse, savings on treatment costs, and a reduction in fresh reagent dosing. Thus, the aim of this study is to ascertain whether there are ions in flotation with dominant effects on the gangue depression of a Merensky ore. Talc is used as proxy for the naturally floatable gangue common in Merensky ores.

\section{MATERIALS AND METHODS}

\section{Synthetic Plant Water and Single Salt Quality}

Synthetic plant water (hereafter referred to as 1SPW or 1Plant) and various single salt solutions of the ionic strength and the chemical compositions shown in Table 1 were prepared. These aqueous synthetic plant water and single salt solutions were made from distilled water and inorganic salts to ensure that the concentration of the water contained the required total dissolved solids and ionic strength as shown in Table $\mathbf{1 .}$

\section{Ore Preparation and Milling}

A Cu-Ni-PGM-containing ore from the Merensky reef, within the Bushveld Igneous Complex of South Africa, was used throughout the bench-scale flotation tests. The bulk sample was crushed, riffled, and split into samples weighing $1 \mathrm{~kg}$ using a rotary splitter. The 1-kg ore samples were milled in a tumbling mill in the presence of the particular water type under study in order to make a slurry of $66 \%$ solids in the mill at the end of milling. Sodium isobutyl xanthate, which was supplied by Senmin, was used as the collector and dosed into the mill at a dosage of $150 \mathrm{~g} / \mathrm{t}$. The mill was operated so as to achieve a grind size of $60 \%$ passing $75 \mu \mathrm{m}$. It is important to note that this grind is typical of industrial concentrator rougher circuits concentrating on Merensky ores. The grinding media was comprised of 20 stainless steel rods with varying diameters: $6 \times$ $25 \mathrm{~mm}, 8 \times 20 \mathrm{~mm}, 6 \times 16 \mathrm{~mm}$. The milled slurry was transferred into a 3-L UCT Barker batch flotation cell immediately. The mineral composition of this ore is shown in Table 2. Pyrrhotite, pentlandite, and chalcopyrite are the main base metal sulfides; these form about $1 \%$ of the overall ore feed grade, with the rest being gangue minerals.

\section{Batch Flotation}

The standard UCT bench-scale batch flotation procedure was employed on a 3-L Barker cell. The milled slurry was transferred to the cell, and the single salt solution under investigation was added to the cell in order to ensure a pulp density of $35 \%$; thereafter, the impeller was switched on and set to an agitation speed of 1,200 rpm. A syringe was used to draw out a feed sample (which would later be filtered, dried, and weighed for $\mathrm{Cu}, \mathrm{Ni}$, and $S$ assays). A polyglycol frother in the form of DOW 200 supplied by Betachem was added to the cell at a dosage of $40 \mathrm{~g} / \mathrm{t}$ and allowed to condition for $1 \mathrm{~min}$, after which the air supply valve to the cell was opened in order to ensure a constant volumetric air flow rate of $7 \mathrm{~L} / \mathrm{min}$. A froth build-up occurred until a constant froth height of $2 \mathrm{~cm}$. Four concentrates were scraped in 15-s 
intervals and collected at 2, 4, 6, and 10 min into concentrate dishes named C1, C2, C3, and C4, respectively. Once all of the four concentrates were collected, the air supply was switched off; a tails sample was also taken thereafter. The concentrates were weighed in order to account for the amount of water reporting to the concentrate, and thereafter the samples were filtered, dried, weighed, and analyzed for $\mathrm{Cu}, \mathrm{Ni}$, and $\mathrm{S}$ in the UCT Chemical Engineering Analytical Services Laboratory using XRF and Leco. All tests were performed in duplicates, and the error bars are shown in the batch flotation results. Batch flotation tests were performed at room temperature $\left(25^{\circ} \mathrm{C}\right)$.

\section{Solid Settling Tests}

Settling tests were performed for single salt solutions of $\mathrm{CaCl}_{2}$, $\mathrm{CaSO}_{4}, \mathrm{Ca}\left(\mathrm{NO}_{3}\right)_{2}, \mathrm{NaCl}, \mathrm{NaNO}_{3}$, and $\mathrm{Na}_{2} \mathrm{SO}_{4}$ at a total ionic strength of $0.0213 \mathrm{~mol} \mathrm{dm}{ }^{-3}$, with each test performed in duplicate. These salts were carefully selected as they showed the most interesting effects on gangue recovery during the flotation of the selected $\mathrm{Cu}-\mathrm{Ni}-\mathrm{PGM}$ ore. Nine grams of Merensky ore were added to $90 \mathrm{ml}$ of the water under investigation in a 100$\mathrm{ml}$ glass beaker to make a slurry containing $10 \%$ solids. The contents of the glass beaker were mixed adequately for $1 \mathrm{~min}$ using a magnetic stirrer. The $\mathrm{pH}$ of the suspension was adjusted to $\mathrm{pH} 9$ using stock/dilute solutions of $\mathrm{NaOH}$ or $\mathrm{HCl}$. The suspension was allowed to mix at $500 \mathrm{rpm}$ for $4 \mathrm{~min}$ in order to disperse the mixture immediately after $\mathrm{pH}$ adjustment. The slurry was then carefully transferred to a $100-\mathrm{ml}$ graduated cylinder. The graduated cylinder was carefully monitored until a clear supernatant liquid was observed against a clear background. A picture was taken, printed, and stuck next to the working bench to serve as a basis for the clear supernatant liquid for the remaining tests. The time taken to reach equivalent settling was recorded. Settling tests were conducted at room temperature $\left(25^{\circ} \mathrm{C}\right)$.

\section{Zeta Potential Measurements on Talc}

A Malvern Zetasizer 4 was used to measure the zeta potential of talc at varying $\mathrm{pH}$ values. Talc was crushed using a hammer and pulverized thereafter. This was sieved and screened to $100 \%$ passing $25 \mu \mathrm{m}$. Single salt solutions of $\mathrm{Ca}\left(\mathrm{NO}_{3}\right)_{2}, \mathrm{CaSO}_{4}$, $\mathrm{NaNO}_{3}$, and $\mathrm{Na}_{2} \mathrm{SO}_{4}$ were used as dispersants on the Malvern Zetasizer $4 . \mathrm{Mg}^{2+}$ salts were excluded since $\mathrm{Ca}^{2+}$ and $\mathrm{Mg}^{2+}$ showed similar flotation results. $\mathrm{Na}^{+}$salts were included since these showed different flotation results compared to the two $\left(\mathrm{Ca}^{2+}\right.$ and $\left.\mathrm{Mg}^{2+}\right)$ divalent cations. Furthermore, zeta potential measurements on talc, performed in the presence of $\mathrm{CaCl}_{2}$, $\mathrm{MgCl}_{2}$, and $\mathrm{NaCl}$, are reported in Manono et al. (2019); hence, they are not shown in this paper. For each tested single salt solution [i.e., $\mathrm{Ca}\left(\mathrm{NO}_{3}\right)_{2}, \mathrm{CaSO}_{4}, \mathrm{NaNO}_{3}$, or $\mathrm{Na}_{2} \mathrm{SO}_{4}$ ], six aliquots of $25 \mathrm{ml}$ were measured and were adjusted to $\mathrm{pH}$ values of $2,4,6,8,10$, and 12 using $\mathrm{NaOH}$ and $\mathrm{HCl}$. These were allowed to condition for $20 \mathrm{~min}$. Thereafter, $0.0625 \mathrm{~g}$ of talc was added to the $25 \mathrm{ml}$ conditioned dispersant, stirred, and left to stand for $1 \mathrm{~min}$. Two milliliters of the supernatant solution was then pipetted into the capillary tube and placed into the Malvern Zetasizer 4. A calibration time of 2 min was allowed, and each reading was taken three times. This procedure was repeated for
TABLE 2 | Modal composition: sulfide and gangue minerals present in the ore as determined by QEMSCAN.

\begin{tabular}{lc}
\hline Mineral & $\%$ \\
\hline Pentlandite & 0.31 \\
Chalcopyrite & 0.25 \\
Pyrrhotite & 0.44 \\
Pyrite & 0.08 \\
Other sulfides & 0.02 \\
Total sulfides & 1.09 \\
Plagioclase & 43.38 \\
Orthopyroxene & 32.60 \\
Olivine & 0.59 \\
Clinopyroxene & 7.48 \\
Talc & 3.51 \\
Serpentine & 0.80 \\
Chlorite & 0.83 \\
Phlogopite & 0.46 \\
Quartz & 0.67 \\
Calcite & 0.18 \\
Oxides & 8.10 \\
Other & 0.32 \\
Total & 100.00 \\
\hline
\end{tabular}

all the different dispersants. Zeta potential measurements were conducted at room temperature $\left(25^{\circ} \mathrm{C}\right)$.

\section{Inorganic Electrolyte Speciation}

In order to investigate specific ion effects on interactions occurring in the pulp phase of flotation at the solid-water interface, inorganic electrolyte speciation calculations were carried out using the Visual MINTEQ (version 3.1). The Visual MINTEQ is an open-source chemical equilibrium modeling software for the prediction or calculation of ion speciation in water based on thermodynamic equilibrium data (Wang et al., 2016). Only single salt solutions of $\mathrm{Ca}\left(\mathrm{NO}_{3}\right)_{2}, \mathrm{CaSO}_{4}, \mathrm{NaNO}_{3}$, and $\mathrm{Na}_{2} \mathrm{SO}_{4}$ were subjected to the Visual MINTEQ for ion speciation over a $\mathrm{pH}$ range of $2-12$. Temperature was set at $25^{\circ} \mathrm{C}$.

\section{Statistical Analyses}

Statistical analyses were carried out using the Minitab 18.1 Analysis of Means (ANOM). This method uses the output means (e.g., \%S grades) for all conditions and calculates an overall or grand mean. It then compares the single test condition output against the total grand mean calculated from all conditions. This would be such that if an output mean for a specific condition falls below the lower bound of the confidence interval, it would be said that the specific test condition resulted in an output mean significantly lower than the total grand mean, whereas if the output fell outside the upper bound of the $95 \%$ confidence interval, that condition is said to have resulted in an output that is significantly higher than the total grand mean. However, if a specific test condition resulted in an output that fell within the confidence interval, that output is said to be comparable with the total grand mean (i.e., there is no discernable statistical 
difference between that specific test condition's finding and the total grand mean, and therefore it cannot be said that the specific test condition resulted in a lower or higher impact compared to the other tested conditions).

\section{RESULTS}

\section{The Effect of Single Salts on Total Sulfides, Gangue and Water Recoveries, and Total Sulfide Grades}

Figure 1 shows the total mass pull (i.e., the total amount of solids reporting to the concentrate) for all the inorganic electrolytic

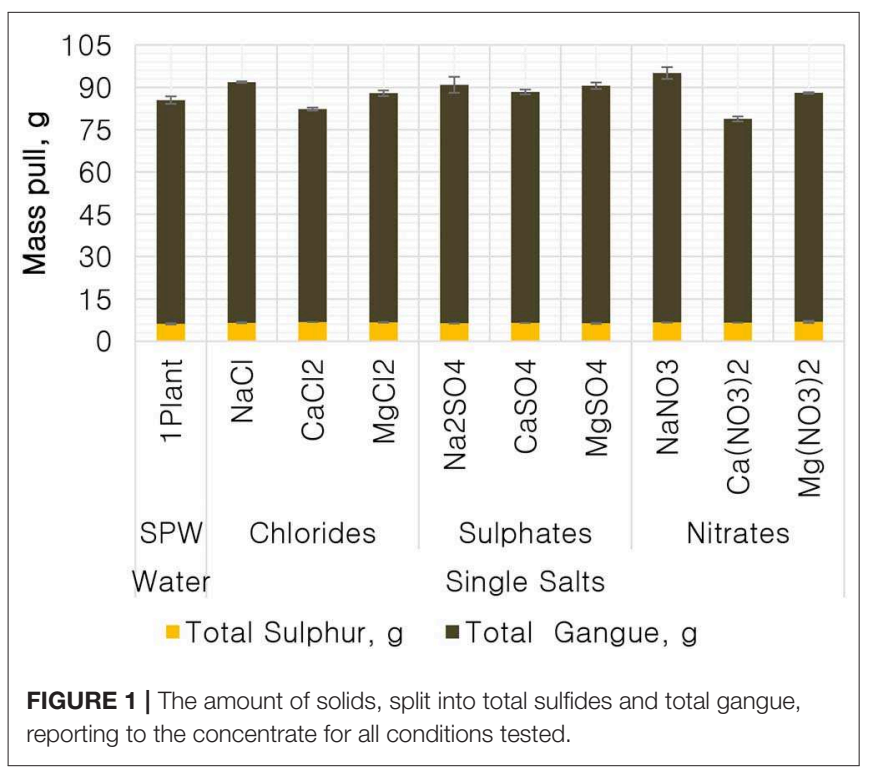

solutions. The mass pull is presented as two fractions, namely, the sulfides and the gangue. It is shown that the amount of sulfides reporting to the concentrate did not change with single salt type and the recovered mass of sulfides was the same as that recovered in the presence of synthetic plant water; these results are further supported by the ANOM performed on these data in Figures 2, 3, where it is shown that there is no significant difference between the means of the mass of sulfides obtained with different single salts and of that obtained with synthetic plant water. However, the amount of gangue reporting to the concentrate showed a dependence on the ions present in the single salt solution. $\mathrm{Ca}\left(\mathrm{NO}_{3}\right)_{2}$ and $\mathrm{CaCl}_{2}$ resulted in a significant decrease in total gangue recovery compared to other single salts, while $\mathrm{NaNO}_{3}$ resulted in a significant increase in gangue reporting to the concentrate as shown in Figure 3.

Figure 4 shows the total sulfide recoveries and grades for all tested single salts and synthetic plant water. It is clear that the $\% \mathrm{~S}$ recovery remained unaffected by changes in the inorganic electrolyte solution type, whereas the $\% \mathrm{~S}$ grade proved to be susceptible to changes in the quality of the ionic solution as illustrated in Figures 5, 6. $\mathrm{Ca}\left(\mathrm{NO}_{3}\right)_{2}$ and $\mathrm{CaCl}_{2}$ resulted in significantly higher concentrate grades compared to all the other single salts as can be seen in Figure 6. It is also interesting to note that the $\mathrm{Na}^{+}$-containing single salt solutions resulted in grades slightly lower than the grand mean shown by the ANOM presented in Figure 6.

Figure 7 shows the $\% \mathrm{~S}$ recovery as a function of the amount of water recovered for all tested single salts. According to Figure 7, all tested single salt solutions and synthetic plant water generally followed the same trend of a first-order model. It is shown that there was no difference in the recovery of total sulfides per gram of water regardless of the inorganic electrolyte solution used.

Figure $\mathbf{8}$ depicts the recovery of gangue per gram of water for the various single salts and the synthetic plant water. It is evident

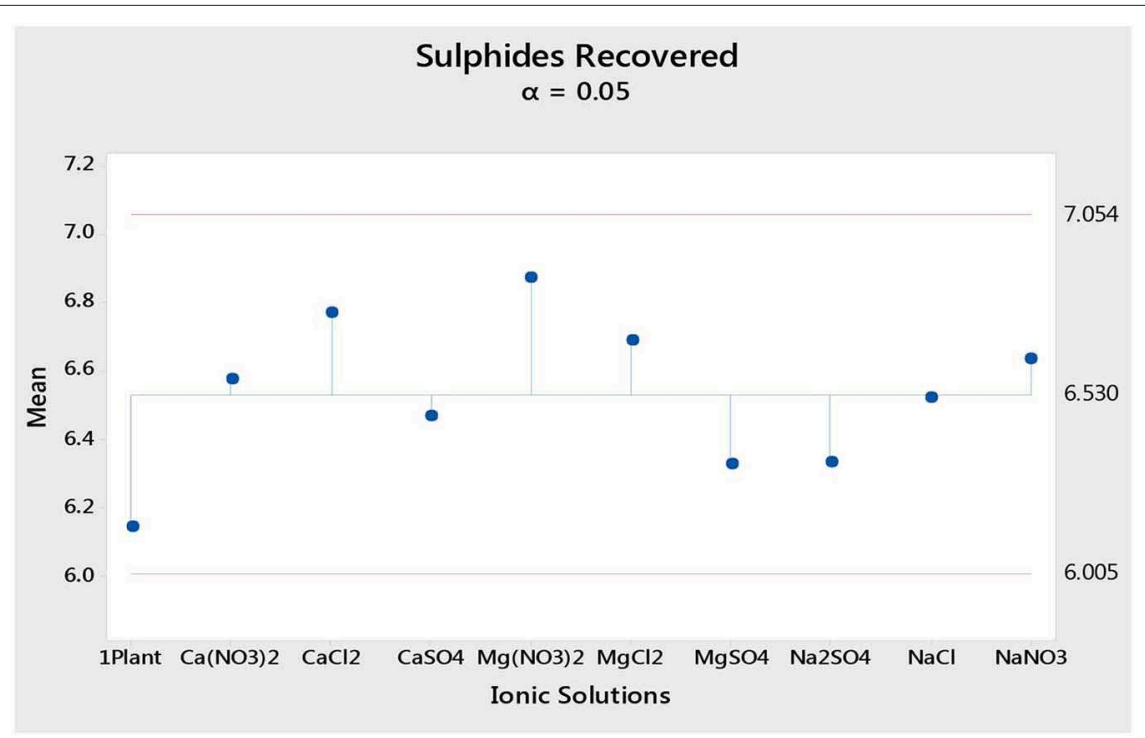

FIGURE 2 | Analysis of means of the amount of sulfides (in grams) reporting to the concentrate for all single salts and synthetic plant water. 


\section{ANOM for Gangue Recovered \\ $\alpha=0.05$}

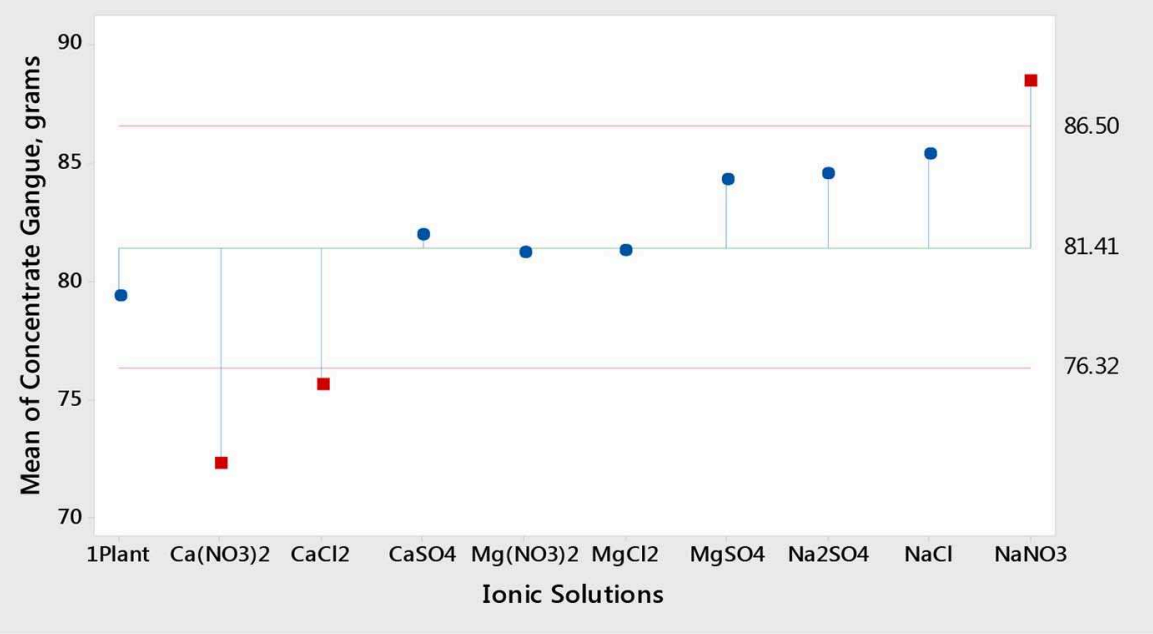

FIGURE 3 | Analysis of means (ANOM) of the amount of gangue reporting to the concentrate for all single salts and synthetic plant water.

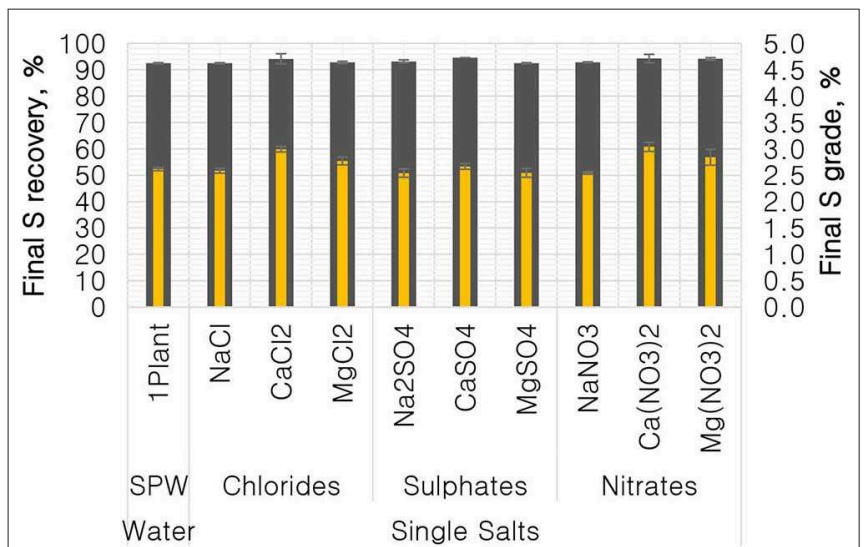

- Suphides recovery, \% $=$ Sulphides grade, \%

FIGURE 4 | Total sulfide recoveries and grades for all single salts and synthetic plant water.

that all single salt solutions containing the monovalent $\mathrm{Na}^{+}$ resulted in higher gangue recovery per gram of water compared to that of the synthetic plant water and the single salt solutions containing divalent cations $\left(\mathrm{Ca}^{2+}\right.$ and $\left.\mathrm{Mg}^{2+}\right) \cdot \mathrm{Ca}^{2+}$ - and $\mathrm{Mg}^{2+}$ containing single salt solutions resulted in lower gangue per gram of water compared to that of synthetic plant water. Furthermore, for the $\mathrm{Na}^{+}$single salts, gangue recovery per gram of water was higher in the $\mathrm{SO}_{4}{ }^{2-}$ solution compared to the $\mathrm{Cl}^{-}$- and $\mathrm{NO}_{3}^{-}$containing solutions. Moreover, of the divalent cation-containing single salts, $\mathrm{Ca}^{2+}$ resulted in lower gangue recovery per gram of water compared to $\mathrm{Mg}^{2+}$.

\section{The Effect of Single Salts on the} Coagulation of the Selected Merensky Ore Figure 9 shows the settling time of solids for a Merensky ore for various single salts as a proxy to cationic and anionic effect on coagulation. The $\mathrm{Na}^{+}$-containing solutions resulted in longer settling times compared to the $\mathrm{Ca}^{2+}$-containing solutions for every corresponding anion, suggesting a cation effect on coagulation with the divalent cation having a stronger coagulation effect compared to the monovalent cation. Moreover, for a fixed cation, $\mathrm{SO}_{4}{ }^{2-}$ resulted in the longest settling time followed by $\mathrm{Cl}^{-}$, while the $\mathrm{NO}_{3}^{-}$anions resulted in the shortest settling time.

\section{The Effect of Single Salts on the Zeta Potential of Talc}

Figure 10 depicts the zeta potential of talc as a function of $\mathrm{pH}$ in various single salt solutions in order to investigate whether there are any ion (anion and cation)-specific effects on the zeta potential of talc. Firstly, it is evident that the monovalent $\mathrm{Na}^{+}$resulted in a highly negative zeta potential of talc across the studied $\mathrm{pH}$ range compared to solutions containing the divalent $\mathrm{Ca}^{2+}$. Secondly, for both cations, $\mathrm{NO}_{3}^{-}$resulted in a less negative zeta potential compared to $\mathrm{SO}_{4}{ }^{2-}$ across the studied $\mathrm{pH}$ range. Generally at $\mathrm{pH}>4, \mathrm{Ca}^{2+}$-containing single salt solutions resulted in an increase in the potential of talc with increasing $\mathrm{pH}$, to an extent that the zeta potential of talc became positive after $\mathrm{pH}$ 8 for $\mathrm{Ca}\left(\mathrm{NO}_{3}\right)_{2}$. However, an increase in $\mathrm{pH}$ resulted in a further decrease in the potential of talc in $\mathrm{Na}^{+}$-containing solutions. A point of zero potential for talc is seen at $\mathrm{pH} 2$ in $\mathrm{NaNO}_{3}$, while two points of zero potential for talc are seen with $\mathrm{Ca}\left(\mathrm{NO}_{3}\right)_{2}$ at $\mathrm{pH} 3$ and $\mathrm{pH}$ 9. It is worth noting that at $\mathrm{pH} 4$ the two $\mathrm{SO}_{4}{ }^{2-}$-containing solutions resulted in similar talc potentials. 


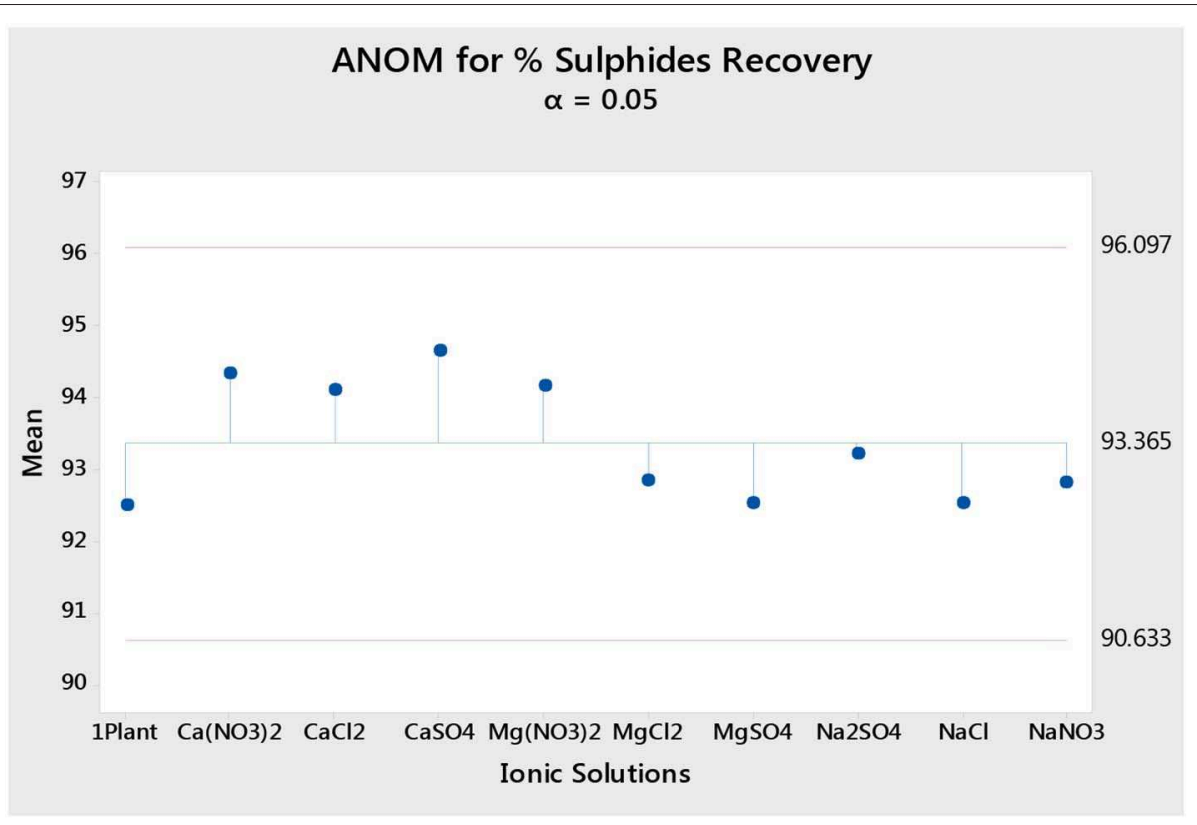

FIGURE 5 | Analysis of means (ANOM) of the total sulfide recovery for all single salts and synthetic plant water.

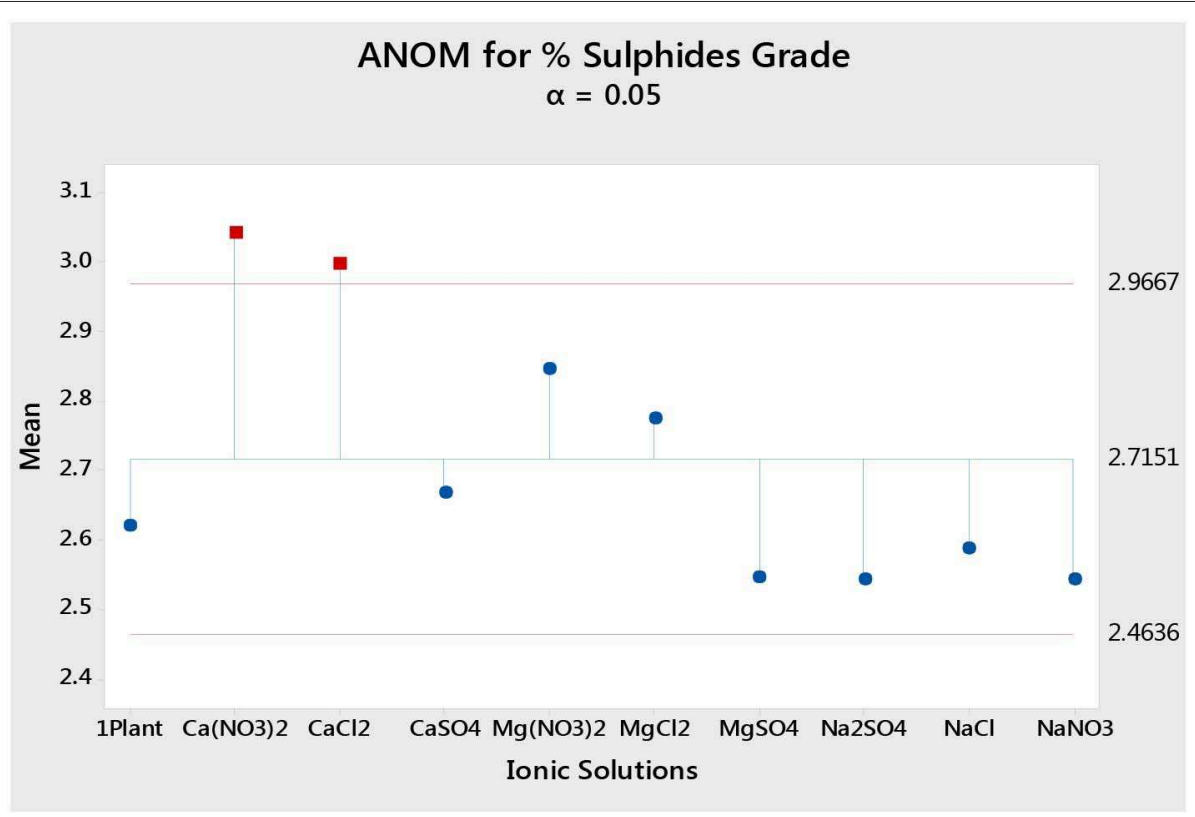

FIGURE 6 | Analysis of means (ANOM) of the total sulfides grade for all single salts and synthetic plant water.

\section{The Speciation of Selected Single Salt Solutions}

Figure 11 depicts the speciation of a $\mathrm{NaNO}_{3}$ solution, with an ionic strength of $0.0213 \mathrm{~mol} \mathrm{dm}^{-3}$, generated through the Visual MINTEQ 3.1 software. The speciation of $\mathrm{NaNO}_{3}$ shows that at $\mathrm{pH} 4$ and below, the dominant species are $\mathrm{Na}^{+}, \mathrm{NO}_{3}^{-}$, and $\mathrm{H}^{+}$, with all of the other species existing at comparably insignificant concentrations. At the $\mathrm{pH}$ range of 4-10, only $\mathrm{Na}^{+}$ and $\mathrm{NO}_{3}^{-}$are dominant and present in solution. Beyond $\mathrm{pH}$ 10 , the concentration of $\mathrm{OH}^{-}$rises together with the apparent formation of $\mathrm{NaOH}(\mathrm{aq})$ and $\mathrm{NaNO}_{3}(\mathrm{aq})$.

Figure 12 depicts the speciation of a $\mathrm{Na}_{2} \mathrm{SO}_{4}$ solution, with an ionic strength of $0.0213 \mathrm{~mol} \mathrm{dm}^{-3}$, generated through Visual MINTEQ 3.1 software. The speciation of $\mathrm{Na}_{2} \mathrm{SO}_{4}$ shows that 


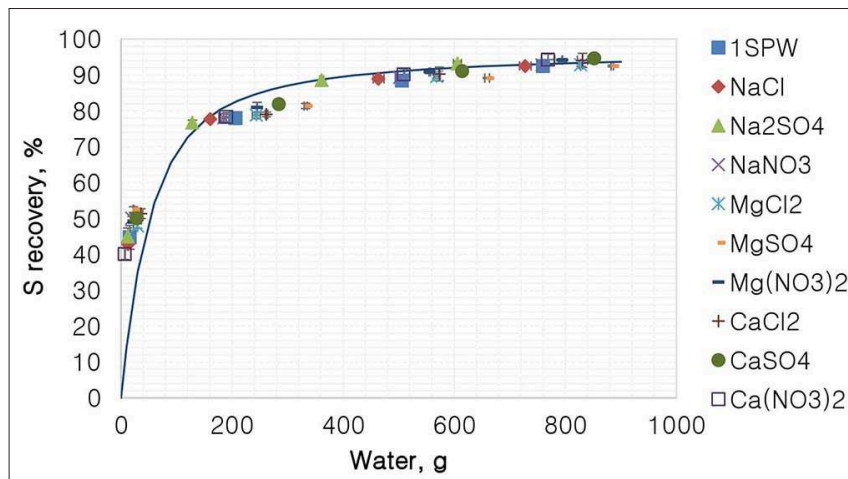

FIGURE 7 | The \%S recovery vs. water for all single salts and synthetic plant water.

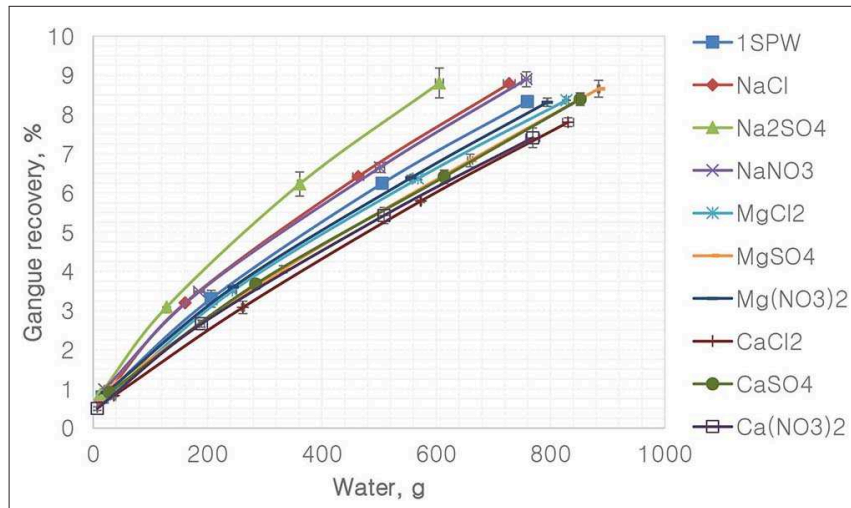

FIGURE 8 | Gangue recovery vs. water for all single salts and synthetic plant water.

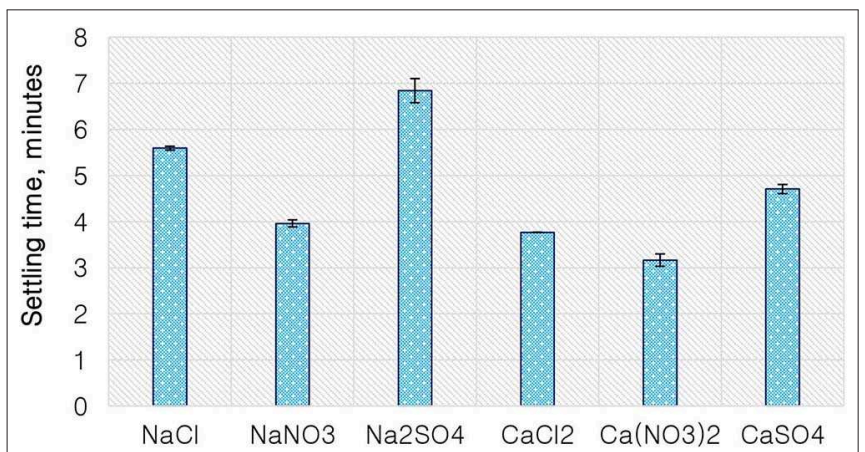

FIGURE 9 | Merensky ore solids settling time as a function of the single salts.

below $\mathrm{pH} 4$, contrary to the $\mathrm{NaNO}_{3}$ speciation, the dominant species are $\mathrm{Na}^{+}, \mathrm{H}^{+}$, and $\mathrm{SO}_{4}{ }^{2-}, \mathrm{HSO}_{4}^{-}$as well as $\mathrm{NaSO}_{4}$. The concentration of these species remains fairly constant in the $\mathrm{pH}$ 4-10 range, except for $\mathrm{HSO}_{4}^{-}$and $\mathrm{H}^{+}$which become virtually insignificant, while the concentration of $\mathrm{OH}^{-}$rises together with an appearance of $\mathrm{NaOH}(\mathrm{aq})$ and $\mathrm{NaSO}_{4}^{-}$when the $\mathrm{pH}$ is increased beyond $\mathrm{pH} 10$. It is important to note that the specific $\mathrm{Na}^{+}$concentration in $\mathrm{Na}_{2} \mathrm{SO}_{4}$ is roughly $0.014 \mathrm{~mol}$

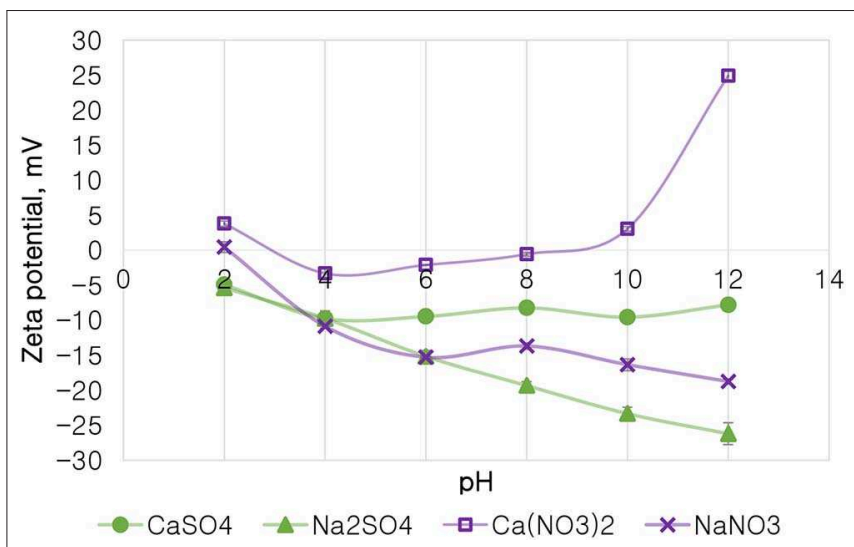

FIGURE 10 | The zeta potential of talc in single salt solutions of $0.0213 \mathrm{~mol}$ $\mathrm{dm}^{-3}$ ionic strength as a function of $\mathrm{pH}$.

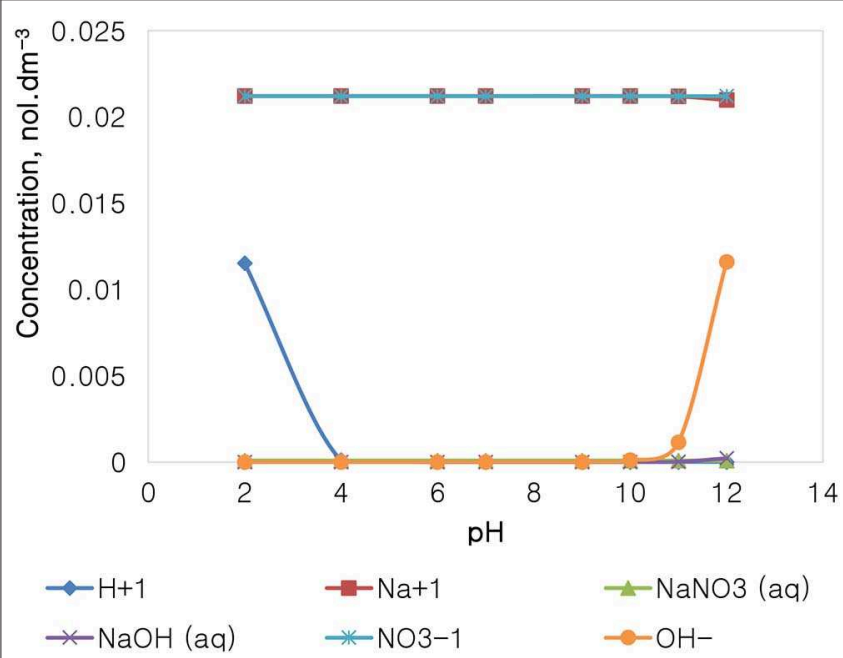

FIGURE 11 | $\mathrm{NaNO}_{3}$ speciation for a solution of $0.0213 \mathrm{~mol} \mathrm{dm} \mathrm{m}^{-3}$ ionic strength.

$\mathrm{dm}^{-3}$, relatively lower than that of $0.021 \mathrm{~mol} \mathrm{dm}{ }^{-3}$ in $\mathrm{NaNO}_{3}$ as reported in Figure 11, although both single salts have a fixed similar ionic strength of $0.021 \mathrm{~mol} \mathrm{dm}^{-3}$. The $\mathrm{NO}_{3}^{-}$ion in $\mathrm{NaNO}_{3}$ also has a higher concentration compared to the concentration of $\mathrm{SO}_{4}{ }^{2-}$ seen in $\mathrm{Na}_{2} \mathrm{SO}_{4}$.

Figure 13 depicts the speciation of a $\mathrm{Ca}\left(\mathrm{NO}_{3}\right)_{2}$ solution, with an ionic strength of $0.0213 \mathrm{~mol} \mathrm{dm}^{-3}$, generated through the Visual MINTEQ 3.1. The speciation of $\mathrm{Ca}\left(\mathrm{NO}_{3}\right)_{2}$ shows that at pH 4 and below, the dominant species are $\mathrm{Ca}^{2+}, \mathrm{NO}_{3}^{-}$, and $\mathrm{H}^{+}$, with all of the other species existing at comparably insignificant concentrations. At the $\mathrm{pH}$ range of $4-10$, only $\mathrm{Ca}^{2+}$ and $\mathrm{NO}_{3}^{-}$ are dominant and present in the solution, with a concentration of $0.014 \mathrm{~mol} \mathrm{dm}^{-3}$ for the $\mathrm{NO}_{3}^{-}$anions compared to that of the other species. It is also shown that above $\mathrm{pH} 10$, the concentration of $\mathrm{OH}^{-}$rises; however, that concentration is still relatively lower than that of the nitrate anions. 


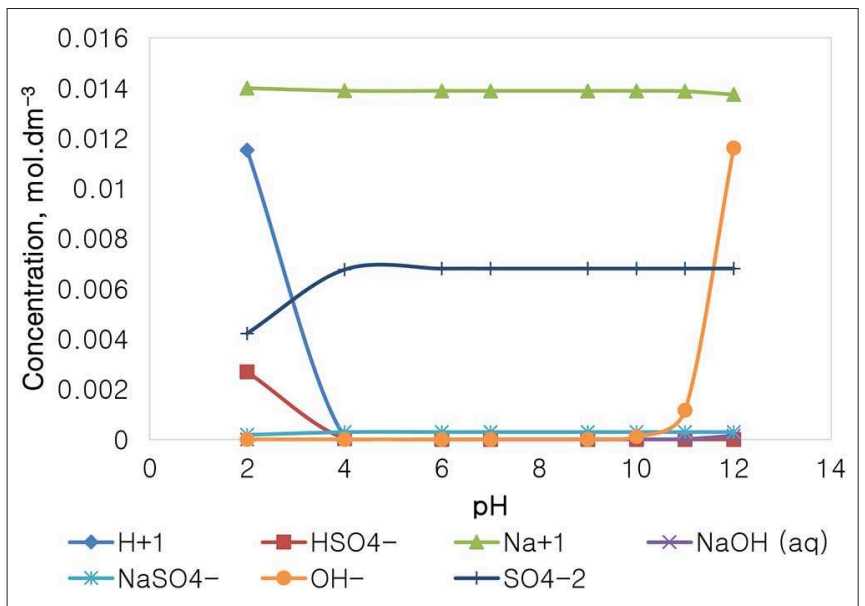

FIGURE 12 | $\mathrm{Na}_{2} \mathrm{SO}_{4}$ speciation for a solution of $0.0213 \mathrm{~mol} \mathrm{dm}-3$ ionic strength.

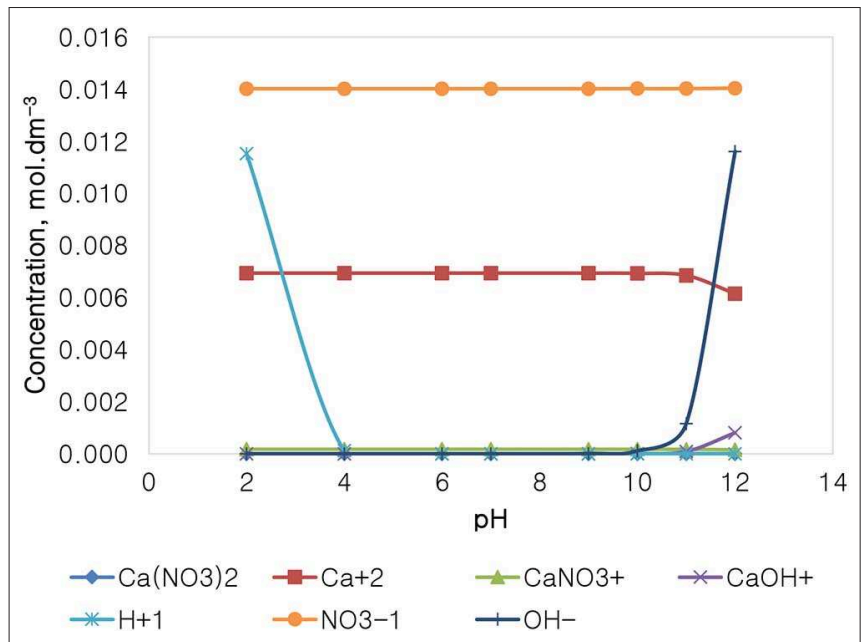

FIGURE 13 | $\mathrm{Ca}\left(\mathrm{NO}_{3}\right)_{2}$ speciation for a solution of $0.0213 \mathrm{~mol} \mathrm{dm}-3$ ionic strength.

Figure 14 depicts the speciation of a $\mathrm{CaSO}_{4}$ solution, with an ionic strength of $0.0213 \mathrm{~mol} \mathrm{dm}^{-3}$, generated through the Visual MINTEQ 3.1. The speciation of $\mathrm{Na}_{2} \mathrm{SO}_{4}$ shows that below $\mathrm{pH} 4$, contrary to the $\mathrm{NaNO}_{3}$ speciation and similarly with that of $\mathrm{Na}_{2} \mathrm{SO}_{4}$, the dominant species are $\mathrm{Ca}^{2+}, \mathrm{H}^{+}$, and $\mathrm{SO}_{4} 2-$, $\mathrm{HSO}_{4}^{-}$, and $\mathrm{CaSO}_{4}$. The concentration of these species remains fairly constant in the $\mathrm{pH} 4-10$, while $\mathrm{H}^{+}$becomes obsolete. The concentration of $\mathrm{OH}^{-}$and of $\mathrm{CaOH}^{+}$increases with an increase in the solution alkalinity, while the concentration of $\mathrm{Ca}^{2+}$ decreases with an increase in $\mathrm{pH}$ beyond $\mathrm{pH}$ 10. It is worth noting that the specific $\mathrm{Ca}^{2+}$ concentration in $\mathrm{CaSO}_{4}$ is roughly $0.004 \mathrm{~mol} \mathrm{dm}^{-3}$, which is relatively lower than that of $0.014 \mathrm{~mol}$ $\mathrm{dm}^{-3}$ in $\mathrm{Ca}\left(\mathrm{NO}_{3}\right)_{2}$ as reported in Figure 12, although both single salts have a fixed similar ionic strength of $0.0213 \mathrm{~mol} \mathrm{dm}^{-3}$. $\mathrm{NO}_{3}^{-}$is also present in higher concentrations $\left(0.062 \mathrm{~mol} \mathrm{dm}^{-3}\right)$ compared to $\mathrm{SO}_{4} 2-\left(0.003 \mathrm{~mol} \mathrm{dm}^{-3}\right)$.

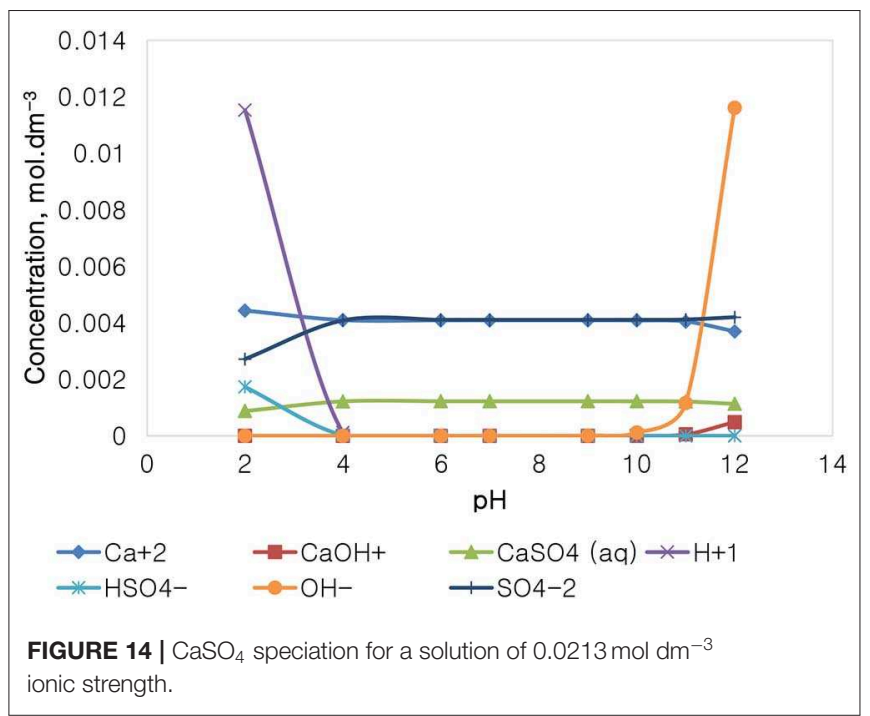

\section{DISCUSSION}

Figures 1, 2 showed no evidence of specific ion effects on sulfide recoveries for the tested ore. Also, Figure 5 shows that the recovery of sulfides per gram of water did not change with ion type, indicating that specific ion effects on froth stability (as measured by the recovery of water) had little or no impact on the behavior of sulfides. However, specific ion effects were observed on the behavior of gangue in that $\mathrm{Ca}\left(\mathrm{NO}_{3}\right)_{2}$ and $\mathrm{CaCl}_{2}$ resulted in the lowest total amount of gangue reporting to the concentrate compared to those of all the other single salts. Figure 3 shows that $\mathrm{NaNO}_{3}, \mathrm{Na}_{2} \mathrm{SO}_{4}$, and $\mathrm{NaCl}$ resulted in the highest total recovery of gangue, while solutions containing $\mathrm{Mg}^{2+}$ were comparable to 1SPW. Figure 8 shows that the monovalent $\mathrm{Na}^{+}$solutions resulted in the highest gangue recovery per gram of water compared to the divalent $\mathrm{Ca}^{2+}$ and $\mathrm{Mg}^{2+}$; this behavior is attributed to the effects on froth stability and the resulting impact on entrainment (Manono et al., 2018a). This behavior could imply that $\mathrm{Na}^{+}$resulted in an activation of gangue, hence the higher gangue recovery per gram of water.

The specific ion effects seen on the behavior of gangue led to $\mathrm{Ca}\left(\mathrm{NO}_{3}\right)_{2}$ and $\mathrm{CaCl}_{2}$ resulting in the highest sulfide grades, whereas all the $\mathrm{Na}^{+}$salts resulted in the lowest sulfide grades compared to the $\mathrm{Ca}^{2+}$ and $\mathrm{Mg}^{2+}$ single salt solutions. Thus, it can be said that the divalent $\mathrm{Ca}^{2+}$ and $\mathrm{Mg}^{2+}$ depressed the gangue more effectively. It was also apparent that in all cations $\left(\mathrm{Ca}^{2+}, \mathrm{Mg}^{2+}\right.$, and $\left.\mathrm{Na}^{+}\right)$, solutions containing $\mathrm{NO}_{3}^{-}$depressed the gangue more readily compared to solutions containing $\mathrm{Cl}^{-}$ and $\mathrm{SO}_{4} 2-$. This effect was stronger in the presence of $\mathrm{Ca}^{2+}$ compared to when a combination of $\mathrm{Na}^{+}$and $\mathrm{NO}_{3}^{-}$was present in the solution.

Findings from the flotation results gave rise to the need to conduct further investigative work into the mechanism of the gangue depression effects seen, hence the determination of specific ion effects on the coagulation and the surface charge of talc. Talc was selected as a proxy for the naturally floatable gangue minerals needing to be depressed during the flotation 
of base metal sulfides-PGM-bearing ores. Single salts which showed the greatest impact on gangue depression and sulfide grades were selected for further investigative test work. Figure 9 shows that the divalent $\mathrm{Ca}^{2+}$ resulted in the shortest settling time compared to the monovalent $\mathrm{Na}^{+}$. This indicates that talc particles coagulated far easier in solutions containing $\mathrm{Ca}^{2+}$ compared to those in $\mathrm{Na}^{+}$-containing solutions. This trend is similar to the observations made in an earlier study by Manono et al. (2019) which showed enhanced coagulation and depression of talc in $\mathrm{CaCl}_{2}$ and $\mathrm{MgCl}_{2}$ compared to those in $\mathrm{NaCl}$. Also, the solutions containing $\mathrm{NO}_{3}^{-}$resulted in a shorter settling time compared to those containing $\mathrm{Cl}^{-}$and $\mathrm{SO}_{4} 2-$. This implies that the $\mathrm{NO}_{3}^{-}$-containing solutions resulted in increased coagulation of talc particles compared to the solutions containing $\mathrm{Cl}^{-}$and $\mathrm{SO}_{4} 2-$. These results are in line with the lower gangue recovery in the solutions containing $\mathrm{Ca}^{2+}$ and $\mathrm{NO}_{3}^{-}$compared to those in the solutions containing $\mathrm{Na}^{+}, \mathrm{Cl}^{-}$, and $\mathrm{SO}_{4} 2-$ as seen in Figure 3.

On the basis of the gangue recovery and the coagulation trends seen in Figures 8, 9, it can be said that there exists specific ion effects on the behavior of gangue in that specific ions such as $\mathrm{Ca}^{2+}$ resulted in slightly more pronounced effects. These effects emanate from the passivation of gangue mineral particle surfaces due to the presence of species such as $\mathrm{Ca}^{2+}$, $\mathrm{CaOH}^{+}$, and $\mathrm{CaNO}_{3}+$ as shown in Figures 11-14. It is evident that beyond $\mathrm{pH}$ 9, oxyhydroxo species and metal complexes become dominant; these alter the surface chemistry of the mineral particles. These oxyhydroxo species are known to impart a more hydrophilic nature on the naturally hydrophobic gangue and thus cause a greater depression of gangue. Zeta potential measurements for talc were taken in various single salts of monovalent and divalent cations to probe the effect of inorganic electrolytes on the particle surface charge. Figure 10 shows that the zeta potential of talc was less negative in $\mathrm{Ca}^{2+}$ compared to that in $\mathrm{Na}^{+}$. These results correlate well with the greater depression and coagulation of gangue in $\mathrm{Ca}^{2+}$ compared to those in $\mathrm{Na}^{+}$as shown in Figures 3, 9. This implies that the non-sulfide gangue mineral particles were more passivated by the presence of the divalent $\mathrm{Ca}^{2+}$ and its resulting oxyhydroxo species in solution such that the surface of the gangue mineral particles would become more hydrophilic. The resulting hydrophilicity would in turn enhance the coagulation of particles and thereby enhance their depression. A similar finding was observed for the anions which resulted in greater depression and coagulation of gangue in that the $\mathrm{NO}_{3}^{-}$-containing solutions in all cation types resulted in a less negative zeta potential, particularly at the natural flotation $\mathrm{pH}$ 9, compared to that of the $\mathrm{SO}_{4} 2$--containing solutions. Furthermore, the zeta potential results as a function of $\mathrm{pH}$ correlate well with the speciation diagrams shown in Figures 11-14 in that the dominant oxyhydroxo species seen at $\mathrm{pH}>9$ are said to passivate mineral surfaces and thereby induce their hydrophilic nature, creating an environment conducive for gangue mineral depression (Laskowski et al., 2007; Ikumapayi et al., 2012; Feng et al., 2013). The coagulation findings of this work are in agreement with those of Dishon et al. (2009) who found that in highly concentrated electrolyte solutions, the adsorption of cations onto the mineral surface changed the surface charge of the particles and resulted in strong attractive forces between particles which consequently formed hydrophilic agglomerates. Similar to what has been shown in this present work on the depression of gangue, an investigation into the role of $\mathrm{Ca}^{2+}$ ions on the surface properties of molybdenite in copper porphyries by Li et al. (2015) showed that the floatability of fine molybdenite particles decreased significantly when $\mathrm{Ca}^{2+}$ ions and silica coexisted in the flotation pulp. Raghavan and Hsu (1984) relate this phenomenon to the adsorption of $\mathrm{Ca}^{2+}$ ions on mineral particles, reducing the magnitude of the negative surface charge and therefore causing the coagulation of mineral particles. As recorded in literature, it is worth mentioning that zeta potential changes also occur as a result of the influence of adsorption of ions onto the mineral surface (Manono et al., 2018b; Michaux et al., 2018). The adsorption of ions on the mineral surface and the resulting change in zeta potential are said to occur either by electrostatic attraction, chemisorption, or chemical reaction. The findings of this work confirm Gaudin (1932) and Gaudin and Charles (1953) who proposed that changes in the potential determining the ion concentration in the solution can cause a reduction in the zeta potential. Furthermore, the resulting correlation between the coagulation and zeta potential trends seen in this work confirms the proposal of a qualitative parallel between coagulation and zeta potential made by Fuerstenau and Mishra (1980) and Fuerstenau et al. (1988).

It is thus evident that the presence of divalent $\mathrm{Ca}^{2+}$ and the resulting oxyhydroxo species in process water causes an adsorption of these inorganic electrolytes onto the mineral surface. These consequently reduce the negative surface charge of the mineral particle as shown by the more positive zeta potential and passivated mineral surface in Figure 10. This in turn leads to enhanced coagulation and depression of gangue.

\section{Graphical Summary of Findings}

From Graphical Abstract, it is therefore proposed that zeta potential measurements and coagulation tests can be used as a tool to test for effects that specific process water constituents will have on the surface chemistry response and floatability of naturally hydrophobic gangue minerals during the flotation of $\mathrm{Cu}-\mathrm{Ni}-\mathrm{PGM}$ ores. Knowledge of such gangue mineral surface chemistry responses to water quality changes may prove beneficial in determining the desired water quality and reagent regimes for uninterrupted flotation performance.

\section{CONCLUSIONS}

The findings of this work have shown that the monovalent $\mathrm{Na}^{+}$ did not promote coagulation. However, in $\mathrm{Ca}^{2+}$, coagulation was favored as less gangue was recovered into the concentrate, indicating an increased gangue depression in the presence of $\mathrm{Ca}^{2+}$ compared to $\mathrm{Na}^{+}$. This trend was more pronounced when $\mathrm{Ca}^{2+}$ was in combination with $\mathrm{NO}_{3}^{-}$. The zeta potential results showed a less negative zeta potential of talc with $\mathrm{Ca}^{2+}$ compared to that with $\mathrm{Na}^{+}$, showing a greater passivation of the mineral surface in $\mathrm{Ca}^{2+}$-containing single salt solutions. The greater 
depression in $\mathrm{NO}_{3}^{-}$was confirmed by the less negative zeta potential, the lower gangue recoveries, and the shorter settling time. Thus, the key findings of this work are:

- Both $\mathrm{NO}_{3}^{-}$and $\mathrm{Ca}^{2+}$ increased the depression of gangue as shown by the lower gangue recoveries.

- The concentrate grades were greater in $\mathrm{Ca}^{2+}$ compared to those in $\mathrm{Na}^{+}$.

- Coagulation and zeta potential tests indicated that $\mathrm{Ca}^{2+}$ and $\mathrm{NO}_{3}^{-}$would mostly likely create a pulp chemistry environment that promotes gangue depression.

- The presence of $\mathrm{Ca}^{2+}$ in flotation process waters could be beneficial for the depression of floatable gangue.

This work has also shown that the depressive action of inorganic electrolytes was more pronounced on gangue, whereas little or no depression action was seen on the valuable sulfides as total sulfide recoveries were generally the same for this specific PGM ore.

\section{DATA AVAILABILITY STATEMENT}

All datasets generated for this study are included in the article/supplementary material.

\section{REFERENCES}

Biçak, Ö., Ekmekçi, Z., Can, M., and Öztürk, Y. (2012). The effect of water chemistry on froth stability and surface chemistry of the flotation of a Cu-Zn sulfide ore. Int. J. Miner. Process. 102-103, 32-37. doi: 10.1016/j.minpro.2011.09.005

Castro, S., Miranda, C., Toledo, P., and Laskowski, J. S. (2013). Effect of frothers on bubble coalescence and foaming in electrolyte solutions and seawater. Int. J. Miner. Process. 124, 8-14. doi: 10.1016/j.minpro.2013.07.002

Corin, K. C., Reddy, A., Miyen, L., Wiese, J. G., and Harris, P. J. (2011). The effect of ionic strength of plant water on valuable mineral and gangue recovery in a platinum bearing ore from the Merensky reef. Miner. Eng. 24, 131-137. doi: 10.1016/j.mineng.2010.10.015

Corin, K. C., and Wiese, J. G. (2014). Investigating froth stability: a comparative study of ionic strength and frother dosage. Miner. Eng. 66, 130-134. doi: 10.1016/j.mineng.2014.03.001

Dishon, M., Zohar, O., and Sivan, U. (2009). From repulsion to attraction and back to repulsion: the effect of $\mathrm{NaCl}, \mathrm{KCl}$ and $\mathrm{CsCl}$ on the force between silica surfaces in aqueous solution. Langmuir 25, 2831-2836. doi: 10.1021/la8 03022b

Feng, Q., Feng, B., and Lu, Y. (2013). Influence of copper ions and calcium ions on adsorption of CMC on chlorite. Trans. Nonferrous Met. Soc. China 23, 237-242. doi: 10.1016/S1003-6326(13)62451-6

Fuerstenau, D. W., and Mishra, R. K. (1980). "On the mechanism of pyrite flotation with xanthate collectors," in Complex Sulphide Ores, eds M. J. Jones (London: I.M.M), 271-277.

Fuerstenau, M. C., Lopez-Valdivieso, A., and Fuerstenau, D. W. (1988). Role of hydrolyzed cations in the natural hydrophobicity of talc. Int. J. Miner. Process. 23, 161-170. doi: 10.1016/0301-7516(88)90012-9

Gaudin, A. M. (1932). Flotation, 1st Edn. New York, NY: McGraw-Hill Book Company.

Gaudin, A. M., and Charles, W. D. (1953). Adsorption of calcium and codium on pyrite. Trans. AIME - Min. Eng. 196, 195-200.

Ikumapayi, F., Makitalo, M., Johansson, B., and Rao, K. H. (2012). Recycling of process water in sulphide flotation: effect of calcium and sulphate ions on flotation of galena. Miner. Eng. 39, 77-88. doi: 10.1016/j.mineng.2012. 07.016

\section{AUTHOR CONTRIBUTIONS}

All authors listed have made a substantial, direct and intellectual contribution to the work, and approved it for publication. MM conceptualized the work, carried out the research experiments, analyzed the experimental data, wrote the manuscript while $\mathrm{KC}$ and JW assisted with conceptualisation, advised on the experimental test work and data analyses, proofread and edited the manuscript.

\section{FUNDING}

This work was supported in part by the National Research Foundation (NRF) of South Africa (Grant number 118062Water Quality in Flotation: Causes, Impacts, and Process Management Strategies). Any opinions, findings, conclusions, or recommendations expressed in any publication generated by NRF supported research is that of the authors and the NRF accepts no liability whatsoever in this regard. Financial and technical contributions from the South African Minerals to Metals Research Institute (SAMMRI) and its members are also acknowledged.

Laskowski, J. S., Liu, Q., and O'Connor, C. T. (2007). Current understanding of the mechanism of polysaccharide adsorption at the mineral/aqueous solution interface. Int. J. Miner. Process. 84, 59-68. doi: 10.1016/j.minpro.2007.03.006

Li, M. Y., Wei, D. Z., Shen, Y. B., Liu, W. G., Gao, S. L., and Liang, G. Q. (2015). Selective depression effect in flotation separation of copper-molybdenum sulfides using 2,3-disulfanylbutanedioic acid. Trans. Nonferrous Met. Soc. China 25, 3126-3132. doi: 10.1016/S1003-6326(15)63942-5

Liu, W., Moran, C. J., and Vink, S. (2014). A review of the effect of water quality on flotation. Miner. Eng. 53, 91-100. doi: 10.1016/j.mineng.2013.07.011

Manono, M., Corin, K., and Wiese, J. (2018a). Water quality effects on a sulfidic PGM ore: Implications for froth stability and gangue management. Physicochem. Probl. Miner. Process. 54, 1253-1265. doi: 10.5277/ppmp 18181

Manono, M., Corin, K., and Wiese, J. (2018b). Perspectives from literature on the influence of inorganic electrolytes present in plant water on flotation performance. Physicochem. Probl. Miner. Process. 54, 1191-1214. doi: $10.5277 /$ ppmp 18157

Manono, M. S., Corin, K. C., and Wiese, J. G. (2016). The influence of electrolytes present in process water on the flotation behaviour of a Cu-Ni containing ore. Miner. Eng. 96-97. doi: 10.1016/j.mineng.2016. 06.015

Manono, M. S., Corin, K. C., and Wiese, J. G. (2019). "Inorganic electrolytes on the efficacy of a carboxymethyl cellulose as a coagulant for talc: implications for talc depression in flotation," in: Mine Water - Technological and Ecological Challenges, eds E. Khayrulina, C. H. Wolkersdorfer, S. Polyakova, and A. Bogush (Perm: Perm State University), 217-225.

Michaux, B., Rudolph, M., and Reuter, M. A. (2018). Challenges in predicting the role of water chemistry in flotation through simulation with emphasis an emphasis on the influence of electrolytes. Miner. Eng. 125, 252-264. doi: 10.1016/j.mineng.2018.06.010

Muzenda, E. (2010). An investigation into the effect of water quality on flotation performance. World Acad. Sci. Eng. Technol. 4, 237-241.

Raghavan, S., and Hsu, L. L. (1984). Factors affecting the flotation recovery of molybdenite from porphyry copper ores. Int. J. Miner. Process. 12, 145-162. doi: 10.1016/0301-7516(84)90026-7 
Rao, S. R., and Finch, J. A. (1989). A review of water re-use in flotation. Miner. Eng. 2, 65-85. doi: 10.1016/0892-6875(89)9 0066-6

Shackleton, N. J., Malysiak, V., De Vaux, D., and Plint, N. (2012). Water quality - a comparative study between moncheite and pentlandite in mixture with pyroxene. Miner. Eng. 36-38, 53-64. doi: 10.1016/j.mineng.2012. 02.004

Wang, X., Liu, R., Ma, L., Qin, W., and Jiao, F. (2016). Depression mechanism of the zinc sulfate and sodium carbonate combined inhibitor on talc. Colloids Surf. A Physicochem. Eng. Aspects 501, 92-97. doi: 10.1016/j.colsurfa.2016. 04.057
Conflict of Interest: The authors declare that the research was conducted in the absence of any commercial or financial relationships that could be construed as a potential conflict of interest.

Copyright (c) 2020 Manono, Corin and Wiese. This is an open-access article distributed under the terms of the Creative Commons Attribution License (CC BY). The use, distribution or reproduction in other forums is permitted, provided the original author(s) and the copyright owner(s) are credited and that the original publication in this journal is cited, in accordance with accepted academic practice. No use, distribution or reproduction is permitted which does not comply with these terms. 